\title{
A Note on the Power of Panel Cointegration Tests - An Application to Health Care Expenditure and GDP
}

\section{Giorgia Marini*}

Sapienza University of Rome, Italy

\begin{abstract}
This paper enlarges on Gutierrez's results on the power of panel cointegration tests. By a comparison of power of panel cointegration tests, we show how the choice of most powerful test depends on the values of the sample statistics. Country-by-country and panel stationarity and cointegration tests are performed on a panel of 20 OECD countries over the period 1971-2004. Residual-based tests and a cointegration rank test in the system of health care expenditure and GDP are used to test cointegration. Asymptotic normal distribution of these tests allows a straightforward comparison for some values of the sample statistics, residual-based and rank tests are not directly comparable as the power of the residual-based tests oscillates; for other values of the sample statistics, the rank test is more powerful than the residualbased tests. This suggests that a clear-cut conclusion on the most powerful test cannot be reached a priori.
\end{abstract}

Keywords: Panel data; Panel stationarity tests; Panel cointegration tests; Power of tests

\section{Introduction}

Since Newhouse [1] seminal paper, research interest has shifted from identifying the proper determinants of health care expenditure [2-5], to checking whether health care is a luxury good [5-11], and more recently to solving the issue of cointegration between health care expenditure and GDP [5,12-21]

The main reason for this change of interests is the extended use of panel data starting from the 1990s [2,3,13]. Advantages and concerns relative to the use of panel data are discussed in various papers [15,22]. One of the main issues raised by the use of panel data is the problem of cointegration of non-stationary variables. Various papers have tried to solve such issue but have reached inconclusive evidence on the matter both on country-by-country and panel tests $[6,12,14,23]$.

The main goal of this paper is to show how the choice of most powerful test actually depends on the empirical values of the statistics. In order to that, we proceed as follows. We first verify the existence of a cointegrating vector of non-stationary health care expenditure and GDP and then we compare the power of three panel cointegration tests to assess which is the most powerful.

Country-by-country and panel stationarity tests and country-bycountry and panel cointegration tests are performed on a panel of 20 OECD countries over the period 1971-2004. Residual-based tests and a cointegration rank test in the system of health care expenditure and GDP are used to test cointegration. Asymptotic normal distribution of these tests allows a straightforward comparison. For some values of the sample statistics, residual-based tests and the cointegration rank test are not directly comparable as the power of the residual-based tests oscillates; for other values of the sample statistics, the residual-based tests and the cointegration rank test are directly comparable and the rank test is more powerful than the residual-based tests.

\section{Data Description}

Health care expenditure (HE) and GDP are measured in national currencies and expressed in 2000 prices (deflated by GDP deflator). Both variables are taken from the OECD Health Dataset [24]. The starting dataset contains a list of 30 OECD countries with annual data covering the period 1960-2005. Due to missing data, Czech Republic,
France, Greece, Hungary, Italy, Korea, Mexico, Poland, Slovak Republic and Turkey have been excluded and the remaining unbalanced panel dataset has a total of $N=20$ countries. The total number of observations is $T=34$ years. Both variables are expressed in logarithm and per capita. As graphical analysis for HE and GDP shows that both series contain a linear trend, ${ }^{1}$ this characteristic is incorporated both into the model specification and into the tests. Description of the model specification and tests is provided in various papers [15,22,25-31]. Therefore, only results for unit root, stationary and cointegration tests are presented.

\section{Results on Stationarity and Cointegration Tests}

Results for country-by-country unit root test (labelled ADF test) and panel unit root test [30] are presented in Table 1.

For HE the unit root hypothesis is only rejected for Germany and Portugal on the $1 \%, 5 \%$ and $10 \%$ level, for Australia and Switzerland on the $5 \%$ and $10 \%$ level, and for Belgium on the $10 \%$ level. For GDP the unit root hypothesis can be rejected for three countries (Austria, Belgium and USA) on the $5 \%$ and $10 \%$ level, and for three countries (Denmark, Finland and Switzerland) on the 10\% level. The panel results fail to reject the I(1) hypothesis for both HE and GDP. In order to check for possible multicollinearity, a country-by-country stationarity test [32] and a panel stationarity test [27], are also performed and reported in Table 2.

For HE the stationarity hypothesis is rejected for six countries (Australia, Austria, Luxembourg, Portugal, Spain, and Switzerland) on the $1 \%, 5 \%$ and $10 \%$ level, for five countries (Canada, Denmark, the Netherlands, Sweden and UK) on the $1 \%$ and $5 \%$ level, and for the ${ }^{1}$ The graphical analysis for HE and GDP has not been included in the paper due to brevity.

*Corresponding author: Giorgia Marini, Department of Law, Philosophy and Economic Studies, Sapienza University of Rome, Piazzale Aldo Moro 5, I-00185 Rome, Italy, Tel: +39 06 49910600; Fax: +39 06 49910648; E-mail: giorgia.marini@uniroma1.it

Received March 18, 2016; Accepted May 06, 2016; Published May 13, 2016

Citation: Marini G (2016) A Note on the Power of Panel Cointegration Tests - An Application to Health Care Expenditure and GDP. Health Econ Outcome Res Open Access 2: 113. doi:10.4172/heor.1000113

Copyright: (c) 2016 Marini G. This is an open-access article distributed under the terms of the Creative Commons Attribution License, which permits unrestricted use, distribution, and reproduction in any medium, provided the original author and source are credited. 


\begin{tabular}{|c|c|c|c|c|}
\hline & \multicolumn{2}{|c|}{ HE } & \multicolumn{2}{c|}{ GDP } \\
\hline & Lags & ADF & Lags & ADF \\
\hline Australia & 1 & -3.772 & 0 & -1.908 \\
\hline Austria & 0 & -2.079 & 0 & -3.913 \\
\hline Belgium & 0 & -3.564 & 0 & -4.109 \\
\hline Canada & 1 & -2.343 & 1 & -2.966 \\
\hline Denmark & 0 & -2.246 & 0 & -2.624 \\
\hline Finland & 1 & -1.957 & 1 & -3.259 \\
\hline Germany & 0 & -4.327 & 0 & -3.534 \\
\hline Iceland & 1 & -2.127 & 1 & -2.562 \\
\hline Ireland & 1 & -1.231 & 2 & -1.589 \\
\hline Japan & 1 & -2.016 & 1 & -1.031 \\
\hline Luxembourg & 2 & -2.171 & 1 & -2.278 \\
\hline Netherlands & 1 & -2.21 & 1 & -2.514 \\
\hline New Zealand & 1 & -2.123 & 1 & -2.115 \\
\hline Norway & 1 & -3.136 & 1 & -3.078 \\
\hline Portugal & 1 & -4.558 & 1 & -3.096 \\
\hline Spain & 1 & -2.395 & 1 & -3.054 \\
\hline Sweden & 1 & -2.119 & 1 & -2.736 \\
\hline Switzerland & 1 & -4.093 & 1 & -3.394 \\
\hline UK & 1 & -2.103 & 1 & -3.174 \\
\hline USA & 1 & -1.79 & 1 & -4.273 \\
\hline IPS panel test & & -0.312 & & -1.548 \\
\hline
\end{tabular}

Note: The maximum lag order for the ADF test ( 8 lags) is by default calculated from the sample size, using a rule provided by Schwert (1989). The $1 \%, 5 \%$ and $10 \%$ critical values are $-4.316,-3.572$ and -3.223 for the country-by-country test and $-2.326,-1.645$ and -1.282 for the panel test.

Table 1: Country-by-country and panel unit root tests.

rest on the $1 \%$ level. For GDP the stationarity hypothesis cannot be rejected for Ireland, while it is rejected for nine countries (Belgium, Canada, Denmark, Finland, Portugal, Sweden, Switzerland, UK and USA) on the $1 \%, 5 \%$ and $10 \%$ level, for four countries (Luxembourg, New Zealand, Norway, and Spain) on the $1 \%$ and $5 \%$ level, and for the rest on the $1 \%$ level. The panel results reject the hypothesis of stationary series for both HE and GDP.

Results relative to country-by-country tests of no cointegration and panel tests of no cointegration (labelled Engle-Granger procedure and IPS test for homogeneous panels and LLC test by [29] for heterogeneous panels, respectively) and country-by-country tests of cointegration and panel tests of cointegration [28,33-35], are presented in Tables 3 and 4, respectively ${ }^{2}$.

From Table 3, the hypothesis of no cointegration is rejected for ten countries on the $1 \%, 5 \%$ and $10 \%$ level, for USA on the $1 \%$ and $5 \%$ level, and for nine countries on the $1 \%$ level. The panel results fail to reject the no cointegration hypothesis.

From Table 4, the hypothesis of cointegration cannot be rejected for all countries except Denmark, Japan, New Zealand and Sweden. The cointegrating rank is determined by the sequential likelihood ratio trace test procedure. Using tests at the $5 \%$ level, a rank $r=1$ is found for 16 countries, indicating that HE and GDP are cointegrated. For the remaining four countries the selected rank is $r=0$, which indicate that $\mathrm{HE}$ and GDP are not cointegrated for these countries. For the panel rank test the hypothesis that the largest rank in the panel is $r=0$ is rejected, but the hypothesis of a largest rank $r=1$ cannot be rejected.

According to the results in Tables 3 and 4, HE and GDP are cointegrated around linear trends for the sample of OECD countries.

${ }^{2}$ We chose the IPS test by [30] and the LLC test by [29] instead of more recent test by [18] because both IPS and LLC tests are constructed as the panel ECM test statistics by pooling across the cross-sectional dimension.

\section{Power of the Panel Tests of Cointegration}

We assume that the estimated values of the three panel tests of co-integration reported that at the bottom of Tables 3 and 4 (IPS, LLC and LLL tests) are the true values of the statistics associated to the data generating process (DGP). The fact that all tests are normally distributed allows comparisons.

We use the sampsi STATA command to draw the power function of the three tests. This command estimates the required power of a test comparing the characteristics of the DGP and the sample. Therefore, for each panel test of cointegration sampsi command tests whether the value of the sample statistics is equal to the value of the statistics associated to the DGP, given the level of significance of the test $(\alpha=0.05)$, the size of the population and sample, and the standard deviation.

When the value of the sample statistics is equal to the value of the statistics associated to the DGP, the test has the minimum power of 0.05 . For values of the sample statistics different from the value of the statistics associated to the DGP, power of the test increases up to maximum power of 1 .

Power of the three tests is represented in Figure 1. The sample statistics takes values between -8.1 and 2.5. Panel tests are directly comparable only for certain values of the statistics. For values between -7.3 and -5.1 the residual-based tests and the rank test are not directly comparable as the power of residual-based tests oscillates. For values between -7.3 and -6.1 , the IPS test is more powerful than the LLC test, and vice versa for values between -6.1 and -5.1 . Over the interval -5.0 and -3.75 , power is not defined, while between -3.75 and -3 only the residual-based IPS test and the rank LLL test are directly comparable: the latter is more powerful than the former.

\begin{tabular}{|c|c|c|}
\hline & HCE & GDP \\
\hline & KPSS & KPSS \\
\hline Australia & 0.101 & 0.188 \\
\hline Austria & 0.079 & 0.147 \\
\hline Belgium & 0.157 & 0.092 \\
\hline Canada & 0.144 & 0.090 \\
\hline Denmark & 0.125 & 0.112 \\
\hline Finland & 0.195 & 0.103 \\
\hline Germany & 0.164 & 0.173 \\
\hline Iceland & 0.178 & 0.161 \\
\hline Ireland & 0.160 & 0.225 \\
\hline Japan & 0.194 & 0.195 \\
\hline Luxembourg & 0.085 & 0.146 \\
\hline Netherlands & 0.132 & 0.148 \\
\hline New & 0.161 & 0.135 \\
\hline New Zealand & 0.157 & 0.132 \\
\hline Portugal & 0.097 & 0.091 \\
\hline Spain & 0.065 & 0.142 \\
\hline Sweden & 0.129 & 0.072 \\
\hline Switzerland & 0.114 & 0.083 \\
\hline UK & 0.127 & 0.113 \\
\hline USA & 0.173 & 0.041 \\
\hline Hadri panel test & 11.442 & 13.621 \\
\hline
\end{tabular}

Note: Since the KPSS test has approximately correct size except when $T$ is small and $I$ is large [32], we exclude the case $I=9$. Following [14], we set lag length $/$ equal to integer $\left[4(\mathrm{~T} / 100)^{1 / 4}\right]$. The $1 \%, 5 \%$ and $10 \%$ critical values are $0.216,0.146$ and 0.119 for the country-by-country test and $-2.326,-1.645$ and -1.282 for the [27] test. Serial dependence in the disturbances is taken into account in the [27] test using a Newey-West estimator of the long run variance.

Table 2: Country-by-country and panel stationary tests. 
Citation: Marini G (2016) A Note on the Power of Panel Cointegration Tests - An Application to Health Care Expenditure and GDP. Health Econ Outcome Res Open Access 2: 113. doi:10.4172/heor.1000113

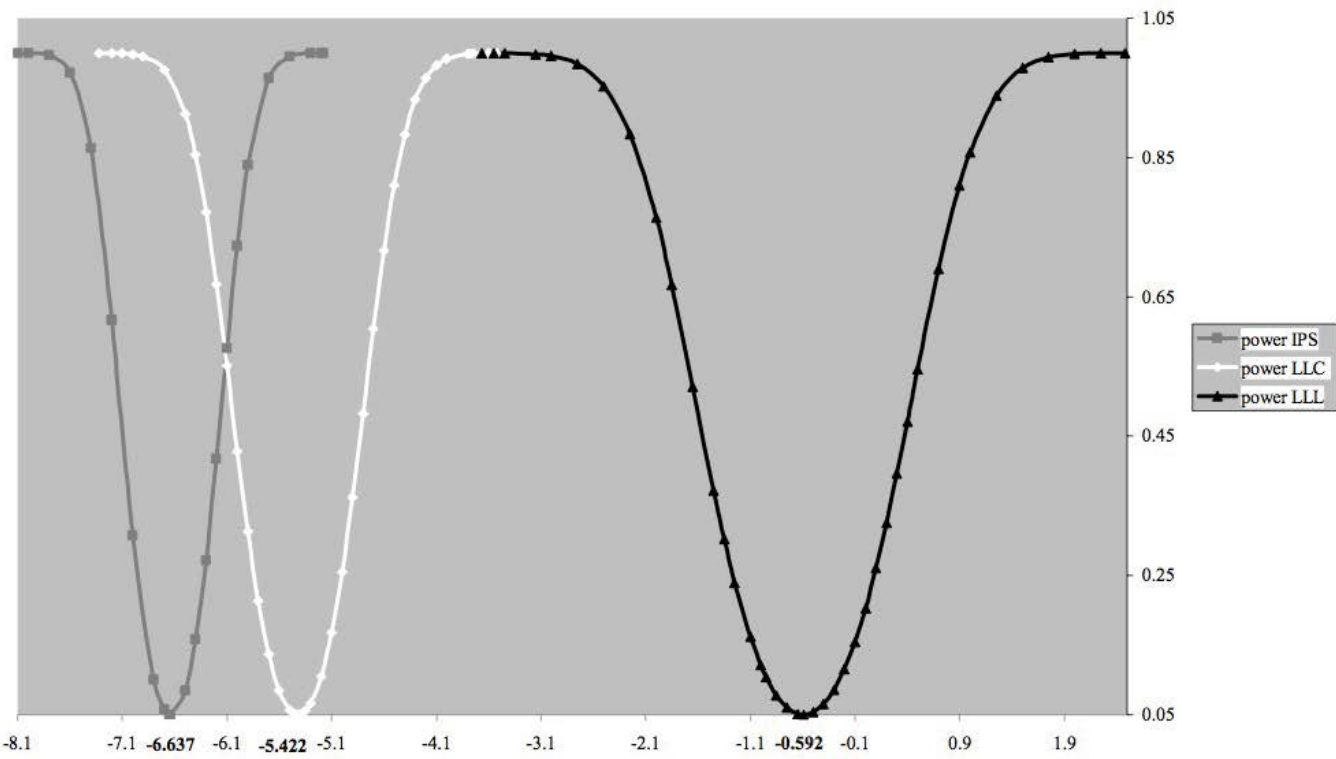

Figure 1: Power of IPS, LLC and LLL tests.

\begin{tabular}{|c|c|c|}
\hline & Lags & Engle-Granger \\
\hline & Lags & Procedure \\
\hline Australia & 1 & -4.137 \\
\hline Austria & 0 & -2.155 \\
\hline Belgium & 0 & -2.647 \\
\hline Canada & 1 & -3.009 \\
\hline Denmark & 0 & -2.494 \\
\hline Finland & 1 & -3.012 \\
\hline Germany & 0 & -4.052 \\
\hline Iceland & 0 & -3.585 \\
\hline Ireland & 1 & -2.925 \\
\hline Japan & 1 & -2.354 \\
\hline Luxembourg & 0 & -1.829 \\
\hline Netherlands & 1 & -3.513 \\
\hline New Zealand & 1 & -2.907 \\
\hline Norway & 0 & -4.18 \\
\hline Portugal & 0 & -3.616 \\
\hline Spain & 2 & -3.888 \\
\hline Sweden & 1 & -2.321 \\
\hline Switzerland & 1 & -3.885 \\
\hline UK & 1 & -3.819 \\
\hline USA & 1 & -3.372 \\
\hline $\begin{array}{l}\text { IPS test for homogeneous } \\
\text { panels }\end{array}$ & \multicolumn{2}{|c|}{-5.422} \\
\hline $\begin{array}{c}\text { LLC test for } \\
\text { heterogeneous panels }\end{array}$ & \multicolumn{2}{|c|}{-6.637} \\
\hline
\end{tabular}

Note: The $1 \%, 5 \%$ and $10 \%$ critical values are $-4.150,-3.500$ and -3.180 for the country-by-country test and $-2.326,-1.645$ and -1.282 for the panel tests.

Table 3: Country-by-country and panel tests of no cointegration.

\section{Conclusion}

This paper offers an alternative way to compare power of panel tests of cointegration based on the comparison between values of the sample statistics and statistics associated to the DGP. The choice of the most powerful test depends on the values of the sample statistics. Both residual-based tests and a cointegration rank test are asymptotically

\begin{tabular}{|c|c|c|c|c|}
\hline \multicolumn{5}{|c|}{ Trace statistics } \\
\hline & Lags & $h=0$ & $h=1$ & Rank $r$ \\
\hline Australia & 1 & 25.162 & 0.27 & 1 \\
\hline Austria & 1 & 51.729 & 1.465 & 1 \\
\hline Belgium & 1 & 91.262 & 3.84 & 1 \\
\hline Canada & 2 & 16.164 & 0.225 & 1 \\
\hline Denmark & 1 & 10.171 & 0.068 & 0 \\
\hline Finland & 1 & 50.055 & 0.79 & 1 \\
\hline Germany & 1 & 77.617 & 0.316 & 1 \\
\hline Iceland & 1 & 68.978 & 0.154 & 1 \\
\hline Ireland & 1 & 52.91 & 0.006 & 1 \\
\hline Japan & 1 & 88.056 & 5.576 & 0 \\
\hline Luxembourg & 1 & 22.148 & 1.016 & 1 \\
\hline Netherlands & 1 & 51.992 & 0.293 & 1 \\
\hline New Zealand & 1 & 0.347 & 0.014 & 0 \\
\hline Norway & 1 & 113.989 & 1.367 & 1 \\
\hline Portugal & 1 & 65.78 & 0.737 & 1 \\
\hline Spain & 1 & 28.053 & 0.024 & 1 \\
\hline Sweden & 1 & 8.59 & 0.031 & 0 \\
\hline Switzerland & 1 & 17.122 & 0.467 & 1 \\
\hline UK & 3 & 24.41 & 3.508 & 1 \\
\hline USA & 1 & 48.932 & 0.193 & 1 \\
\hline LLL panel test & \multicolumn{2}{|c|}{54.604} & \multicolumn{2}{|c|}{-0.592} \\
\hline
\end{tabular}

Note: Critical values for the trace test are tabulated in [33] and are 15.197 and 3.962 for testing $h=0$ and $h=1$, respectively. The $1 \%, 5 \%$ and $10 \%$ critical values are for the panel tests $2.326,1.645$ and 1.282 .

Table 4: Country-by-country and panel tests of cointegration.

normally distributed, which allows a straightforward comparison. For some values of the statistics, the residual-based LLC test is more powerful than the IPS test, and vice versa for other values. For those value of the statistics such that residual-based test and the rank test is comparable, LLL test is more powerful than residual-based LLC test. Therefore, the choice of the most powerful test is not only an empirical matter but also an open issue without a clear-cut choice. 
Citation: Marini G (2016) A Note on the Power of Panel Cointegration Tests - An Application to Health Care Expenditure and GDP. Health Econ Outcome Res Open Access 2: 113. doi:10.4172/heor.1000113

\section{References}

1. Newhouse JP (1977) Medical care expenditure: a cross-national survey. J Human Res 12: 115-125

2. Gerdtham UG (1992) Pooling international health care expenditure data. Health Economics 1: 217-231.

3. Hitiris T, Posnett J (1992) The determinants and effects of health care expenditure in developed countries. J Health Econom 11: 173-181.

4. Gerdtham UG, Jönsson B, MacFarlan M, Oxley H (1998) The determinants of the health care expenditure in the OECD countries. In: Zweifel P (ed.). Health, the medical profession, and regulation Dordrecht: Kluwer Academic Publishers.

5. Roberts $J(2000)$ Spurious regression problems in the determinants of health care expenditure: a comment on Hitiris (1997) Applied Economics Letters 7 279-283.

6. Blomqvist G, Carter RAL (1997) Is health care really a luxury. Journal of Health Economics 16: 207-229.

7. Getzen TE (2000) Health care is an individual necessity and a national luxury: applying multilevel decision models to the analysis of health care expenditures. Journal of Health Economics 19: 259-270.

8. Freeman DG (2003) Is health care a necessity or a luxury? Pooled estimates of income elasticity from US state-level data. Applied Economics 35: 495-502.

9. Sen A (2005) Is health care a luxury? New evidence from OECD data International Journal of Health Care Finance and Economics 5: 147-164.

10. Di Matteo $L$ (2003) The income elasticity of health care spending. The European Journal of Health Economics 4: 20-29.

11. Yavuz NC, Yilanci V, Ozturk ZA (2013) Is health care a luxury or a necessity or both? Evidence from Turkey. The European Journal of Health Economics 14: $5-10$

12. Hansen P, King A (1996) The determinants of health care expenditure: a cointegration approach. Journal of Health Economics 15: 127-137.

13. Hitiris $T$ (1997) Health care expenditure and integration in the countries of the European Union. Applied Economics 29: 1-6.

14. Gerdtham UG, Löthgren M (2000) On stationary and cointegration of international health expenditure and GDP. Journal of Health Economics 19 461-475.

15. Gerdtham UG, Löthgren M (2002) New panel results on cointegration of international health expenditure and GDP. Applied Economics 34: 1679-1686.

16. Gutierrez $L$ (2003) On the power of panel cointegration tests: a Monte Carlo comparison. Economics Letters 80: 105-111.

17. Jewell T, Lee J, Tieslau M, Strazicich MC (2003) Stationarity of health expenditures and GDP: evidence from panel unit root tests with heterogeneous structural breaks. Journal of Health Economics 22: 313-323.
18. Westerlund $\mathrm{J}$ (2007) Testing for error correction in panel data. Oxford Bulletin of Economics and Statistics 69: 709-748.

19. Baltagi $\mathrm{BH}$, Moscone $\mathrm{F}$ (2010) Health care expenditure and income in the OECD reconsidered: Evidence from panel data. Economic Modelling 27: 804 811.

20. Odubunmi AS, Saka JO, Oke DM (2012) Testing the cointegrating relationship between health care expenditure and economic growth in Nigeria. International Journal of Economics and Finance 4: 99-107.

21. Payne JE, Anderson S, Lee J, Cho MH (2015) Do per capita health care expenditures converge among OECD countries? Evidence from unit root tests with level and trend-shifts. Applied Economics 47: 5600-5613.

22. Banerjee A (1999) Panel data unit roots tests and cointegration: an overview. Oxford Bulletin of Economics and Statistics 61: 607-629.

23. McCoskey SK, Selden TM (1998) Health care expenditure and GDP: pane data unit roots test results. Journal of Health Economics 17: 369-376.

24. OECD (2006) OECD Health Data: A comparative analysis of 30 countries Paris: Credes.

25. Pedroni $P$ (1999) Critical values for cointegration tests in heterogeneous panels with multiple regressors. Oxford Bulletin of Economics and Statistics 61: 653670

26. Kao C (1999) spurious regression and residual-based tests for cointegration in panel data. Journal of Econometrics 90: 1-44.

27. Hadri K (2000) Testing for stationarity in heterogeneous panel data Econometrics Journal 3: 148-161.

28. Larsson R, Lyhagen J, Lothgren M (2001) Likelihood-based cointegration tests in heterogeneous panels. Econometric Journal 4: 109-142.

29. Levin A, Lin CF, Chu CSJ (2002) Unit roots tests in panel data: asymptotic and finite sample properties. Journal of Econometrics 108: 1-24.

30. Im KS, Pesaran MH, Shin Y (2003) Testing for unit roots in heterogeneous panels. Journal of Econometrics 115: 53-74

31. Pedroni P (2004) Panel cointegration: Asymptotic and finite sample properties of pooled time series tests with an application to the PPP hypothesis. Econometric Theory 20: 597-625.

32. Kwiatkowski D, Phillps PCB, Schmitd P, Shin Y (1992) Testing the nul hypothesis of stationary against the alternative of a unit roots. Journal of Econometrics 54: 159-178.

33. Phillps PCB, Ouliaris S (1990) Asymptotic properties of residual based tests for cointegration, Econometrica 58: 168-193.

34. Johansen S (1991) Estimation and hypothesis testing of cointegration vectors in Gaussian vector autoregressive models. Econometrica 59: 1551-1580.

35. Johansen S (1995) Likelihood-based inference in cointegrated vector autoregressive models. Oxford: Oxford University Press.
Citation: Marini G (2016) A Note on the Power of Panel Cointegration Tests - An Application to Health Care Expenditure and GDP. Health Econ Outcome Res Open Access 2: 113. doi:10.4172/heor.1000113
OMICS International: Publication Benefits \& Features Unique features:

Increased global visibility of articles through worldwide distribution and indexing

Showcasing recent research output in a timely and updated manner

Special issues on the current trends of scientific research

Special features:

700 Open Access Journals

50,000 editorial team

Rapid review process

Quality and quick editorial, review and publication processing

Indexing at PubMed (partial), Scopus, EBSCO, Index Copernicus, Google Scholar etc.

Sharing Option: Social Networking Enabled

Authors, Reviewers and Editors rewarded with online Scientific Credits

Better discount for your subsequent articles

Submit your manuscript at: http://www.omicsonline.org/submission 